J.Gipas, November 2018, Volume 2 Nomor 2 ISSN 2599-0152 eISSN 2599-2465

http://jos.unsoed.ac.id/index.php/jgps

\title{
PERBEDAAN ASUPAN ZAT GIZI PASIEN HEMODIALISA DI RSUD dr. DORIS SYLVANUS PALANGKA RAYA
}

\section{Differences in Nutritional Intake of Hemodialysis Patients at RSUD $d r$. Doris Sylvanus Palangka Raya}

Fretika Utami Dewi ${ }^{1}$, Septiani ${ }^{1}$

${ }^{1}$ Prodi DIV Gizi Poltekkes Kemenkes Palangka Raya

Email : dewiutami_f@yahoo.co.id

\begin{abstract}
Hemodialysis is a catabolic process (breakdown of complex compounds into simpler compounds) in which amino acid removal and protein synthesis depletion occurred. This study aims to investigate differences in nutritional intake of hemodialysis patients. This research is Pre-post design. Purposive sampling technique was employed on 13 PGK patients who undertake weekly hemodialysis. Data of protein, sodium, potassium and oral intakes were obtained by interview and 24-hour food recall for 2 consecutive days of pre and post hemodialysis. BM photo book was used during interview and food recall. Data were analyzed using paired t-test. Result of the study: most of samples were female (92\%), ranged at 46-67 years old, graduated from elementary school and not working. Bivariate test showed p value of protein, sodium, potassium and fluid intakes were 0.022, 0.382, 0.075 and 0.836, respectively. Hemodialysis aims to restrain uremia, excessive fluid and electrolyte imbalance that occur in end-stage renal failure patients. Hemodialysis may increase survival rate of patients as it is effectively removing fluids, electrolytes and metabolites.

Conclusion: There was a significant difference in protein intake and insignificant differences in sodium, potassium and fluid intakes of pre and post hemodialysis patients.

Keywords : Hemodialysis, protein, sodium, potassium, liquids
\end{abstract}

\section{ABSTRAK}

Hemodialisis merupakan proses katabolik yang terjadi pengeluaran asam amino melalui dialisat dan penurunan sintesis (pembentukan) protein. Tujuan penelitian untuk mengetahui perbedaan asupan zat gizi pasien hemodialisa. Rancangan penelitian adalah Pre-post design. Jumlah sampel adalah 13 pasien PGK yang menjalani hemodialisis rutin satu kali seminggu dengan teknik purposive sampling. Data asupan protein, natrium, kalium dan cairan melalui oral diperoleh dengan food recall 24 jam selama dua hari berturut-turut pada pre dan post Hemodialisa dengan alat bantu buku photo BM. Data dianalisis menggunakan uji t-berpasangan. Hasil Penelitian : Sampel terbanyak berjenis kelamin perempuan (92\%), range usia 46-67 tahun, tingkat pendidikan dasar dan tidak bekerja. Uji Bivariat asupan protein p value $0,022(\mathrm{p}<0,05)$, asupan natrium $\mathrm{p}$ value $0,382(\mathrm{p}>0,05)$, asupan kalium $\mathrm{p}$ value $0,075(\mathrm{p}>0,05)$ dan asupan cairan $\mathrm{p}$ value $0,836(\mathrm{p}>0,05)$. Tujuan hemodialisa adalah menghilangkan gejala uremia, kelebihan cairan dan ketidakseimbangan elektrolit yang terjadi pada pasien gagal ginjal tahap akhir. Hemodialisa efektif mengeluarkan cairan, elektrolit dan sisa metabolisme tubuh sehingga dapat memperpanjang umur pasien. Kesimpulan : Ada perbedaan bermakna asupan protein pre dan post Hemodialisa dan tidak ada perbedaan bermakna untuk asupan natrium, kalium, cairan pre dan post Hemodialisa.

Kata Kunci : Hemodialisa, protein, natrium, kalium, cairan.

\section{PENDAHULUAN}

Hemodialisis merupakan proses katabolik (pemecahan senyawa komplek menjadi senyawa yang lebih sederhana), di dalam proses hemodialisis terjadi pengeluaran asam amino melalui dialisat
Commented [Y1]: Ini sudah dibuat 2 kolom, mohon jangan diubah2. Sllakan perbaiki di file ini 
dan penurunan sintesis (pembentukan) protein. Selama proses hemodialisis otot akan melepaskan asam-asam amino. Penderita gagal ginjal kronik dengan hemodialisis dianjurkan asupan harian protein seharusnya juga ditingkatkan sebagai kompensasi kehilangan protein, yaitu $1,2 \mathrm{mg} / \mathrm{kg} \mathrm{BB}$ ideal/hari. Protein yang dikonsumsi hendaknya 50\% mengandung nilai biologi tinggi (Almatsier, 2006 dalam Hasanah, 2016)

Menurut data dari The United States Renal Data System (USRDS) tahun 2009 Gagal Ginjal Tahap Akhir (GGTA) sering ditemukan dan prevalensinya sekitar 10-13\%. Di Amerika Serikat jumlahnya mencapai 25 juta orang, dan di Indonesia diperkirakan $12,5 \%$ atau sekitar 18 juta orang (Suhardjono, 2009). Dan dari tahun 2011 pasien yang menjalani hemodialisis meningkat menjadi $27,79 \%$ pada tahun 2012 (IRR, 2013). Berdasarkan data dari RSUD dr. Doris Sylvanus Palangka Raya pada tahun 2015 dari bulan Januari hingga bulan Desember 2015 menunjukkan sebanyak 10505/tindakan. Dan pada tahun 2016 pasien yang menjalani hemodialisa berjumlah 121 orang dengan usia antara 17 sampai 84 tahun. Terapi pengganti untuk penderita gagal ginjal kronik yang
J.Gipas, November 2018, Volume 2 Nomor 2 ISSN 2599-0152 eISSN 2599-2465 http://jos.unsoed.ac.id/index.php/jgps

paling banyak dilakukan di Indonesia adalah hemodialisis. Prosedur hemodialisis dapat menyebabkan kehilangan zat gizi.

Zat gizi yang banyak hilang adalah protein. Selain berfungsi sebagai sumber energi, zat pembangun dan pengatur, protein juga berperan penting dalam transportasi zat besi dalam tubuh. Kurangnya asupan protein akan mengakibatkan transportasi zat besi terhambat sehingga akan terjadi defisiensi besi (Almatsier, 2006 dalam Hasanah, 2016).

Asupan cairan sangat berperan penting dalam terjadinya penambahan berat badan antara waktu dialisis dimana asupan cairan yang berlebihan akan dapat meningkatkan kelebihan cairan. Hasil penelitian yang dilakukan oleh Istanti, 2009, menyatakan bahwa terdapat hubungan yang signifikan antara masukan cairan dan penambahan berat badan dimana semakin banyak masukan cairan maka semakin meningkat berat badan antara dua waktu dialisis dan faktor yang paling berkontribusi pada terjadinya penambahan berat badan antara dua waktu dialisis adalah masukan cairan. Jumlah asupan cairan dibatasi sesuai dengan jumlah air kencing yang ada di 
tambah insensible water loss. Asupan natrium dibatasi guna mengendalikan tekanan darah dan edema (Suwitra, 2006 dalam Annisa, 2016)

Menurut Graber, 2002, pembatasan kalium pada pasien gagal ginjal sangat diperlukan untuk mengontrol ekskresi kalium karena adanya gangguan pada fungsi ginjal yang mengakibatkan hiperkalemia. Pada pasien yang menjalani hemodialisa, prevalensi hiperkalemia sekitar 5-10\%. Hiperkalemia menyebabkan kematian pada $2-5 \%$ pasien dengan gagal ginjal tahap akhir (Watson, 2010 dalam Annisa, 2016)

Penelitian yang dilakukan Nugrahani, 2007, pada pasien Penyakit Ginjal Kronik (PGK) yang menjalani Hemodialisa (HD) rutin minimal 2 bulan menunjukkan bahwa tidak terdapat hubungan antara total asupan protein terhadap kreatinin, serta tidak terdapat hubungan antara proporsi protein terhadap Blood Urea Nitrogen (BUN), albumin dan kreatinin (Sharif, S.S., Taslim, N.A. \& Bukhari, A.,2012). Dalam sekali tindakan HD dengan dialisat tanpa glukosa dapat mengakibatkan hilangnya 8 gram asam amino yang ikut lepas ke dialisat, juga dengan pemberian infus selama tindakan
J.Gipas, November 2018 , Volume 2 Nomor 2 ISSN 2599-0152 eISSN 2599-2465 http://jos.unsoed.ac.id/index.php/jgps

HD dengan asam amino dan glukosa akan menambah lepasnya asam amino ke dialisat. Dengan demikian, semakin lama penderita menjalani tindakan $\mathrm{HD}$, berarti akan semakin banyak juga asam amino yang hilang/keluar bersama dialisat, jika penderita penyakit ginjal kronik tidak dapat mencukupi kebutuhan nutrisinya, maka akan semakin menurun kualitas hidup penderita penyakit ginjal kronik (El, M., Suryani, I. \& S, N.H..,2015).

Penelitian ini bertujuan untuk mengetahui perbedaan asupan zat gizi yang meliputi asupan protein, natrium, kalium dan cairan pasien yang menjalani HD satu kali per minggu baik sebelum maupun sesudah. Hasil penelitian ini harapannya dapat dijadikan dasar untuk lebih mengaktifkan konseling diet pada pasien HD sehingga dapat memperbaiki kualitas hidup penderita.

\section{METODE}

Rancangan

penelitian

menggunakan rancangan Pre-post design. Penelitian dilakukan pada pasien yang menjalani hemodialiasa satu minggu sekali di RSUD dr. Doris Sylvanus Palangka Raya pada bulan Pebruari - Maret 2018. 
J.Gipas, November 2018, Volume 2 Nomor 2 ISSN 2599-0152 eISSN 2599-2465 http://jos.unsoed.ac.id/index.php/jgps

Jumlah sampel diperoleh berjumlah 13 orang, yang diambil dengan teknik purposive sampling. Data primer yang dikumpulkan yaitu karakteristik sampel yang meliputi umur, jenis kelamin, berat badan (BB), tinggi badan (TB), pendidikan dan pekerjaan yang diperoleh dengan cara wawancara. Data BB (pre dan post HD) sampel diperoleh melalui pengukuran BB menggunakan timbangan digital dengan tingkat ketelitian 0,1 kg. Data TB sampel diperoleh melalui pengukuran TB menggunakan microtoice dengan tingkat

\section{HASIL DAN PEMBAHASAN}

Umur adalah lama hidup seseorang yang dihitung berdasarkan tahun penuh. Distribusi frekuensi umur sampel dapat dilihat pada tabel 1 . Distribusi frekuensi berdasarkan Tabel 1. Menunjukan sampel terbanyak adalah yang berumur 46-67 tahun yaitu 10 orang $(77 \%)$ dan paling sedikit berumur 36-45 tahun sebanyak 3 orang (23\%). Distribusi frekuensi berdasarkan berat badan sampel dapat dilihat pada tabel 2 . Berdasarkan tabel 2. Dapat diketahui bahwa dari 13 sampel untuk berat badan pre HD yaitu berkisar dari 40-70 kg dan sampel untuk berat badan post HD yaitu ketelitian $0,1 \mathrm{~cm}$. Data asupan protein, natrium, kalium dan cairan melalui oral diperoleh dengan food recall 24 jam selama dua hari berturut-turut pada pre dan post HD dengan alat bantu buku photo bahan makanan (BM).

Data asupan yang terkumpul diolah dengan komputer menggunakan program nutrisurvey. Analisis data dilakukan secara univariat dan bivariat. Analisis bivariat dengan menggunakan uji t-berpasangan melalui program SPSS versi 20 untuk mengetahui perbedaan asupan zat gizi pasien HD.

berkisar dari 39-67 $\mathrm{kg}$ dengan selisih berkisar dari 0-3 kg.

Distribusi frekuensi berdasarkan jenis kelamin sampel dapat dilihat pada tabel 3. Distribusi frekuensi berdasarkan Tabel 3. Menunjukan bahwa sampel terbanyak adalah berjenis perempuan berjumlah 12 orang (92\%). Distribusi frekuensi berdasarkan pendidikan sampel dapat dilihat pada tabel 4 . Distribusi frekuensi berdasarkan Tabel 4. Menunjukan bahwa sampel terbanyak adalah sampel dengan pendidikan dasar (Sekolah Dasar dan Sekolah Menengah Pertama) yaitu 6 orang $(46,1 \%)$ dan sisanya pendidikan menengah (Sekolah Menengah Atas) sebanyak 5 orang $(38,5 \%)$ serta dengan pendidikan tinggi 
J.Gipas, November 2018, Volume 2 Nomor 2 ISSN 2599-0152 eISSN 2599-2465 http://jos.unsoed.ac.id/index.php/jgps

(Diploma, Sarjana, Magister, Doktor) sebanyak 2 orang $(15,4 \%)$.

Distribusi frekuensi berdasarkan pekerjaan sampel dapat dilihat pada tabel 5. Distribusi frekuensi berdasarkan Tabel 5. Menunjukan bahwa sampel terbanyak adalah dengan kategori sampel tidak bekerja (Ibu Rumah Tangga) yaitu 11 orang (85\%) dan kategori bekerja (Pegawai Negeri Sipil) yaitu 2 orang (15\%).

Distribusi frekuensi berdasarkan asupan protein pre dan post HD sampel dapat dilihat pada tabel 6. Berdasarkan tabel 6. Dapat diketahui bahwa pada pre hemodialisa untuk asupan protein yang diatas kebutuhan ada lima sampel dengan selisih berkisar dari 3,25 - 33,45 gram dan asupan protein yang dibawah kebutuhan ada delapan sampel dengan selisih berkisar dari $(-32,65)-(-7,4)$ gram serta pada post HD untuk asupan protein yang diatas kebutuhan ada 1 sampel dengan selisih 27,2 gram dan asupan protein yang dibawah kebutuhan ada 12 sampel dengan selisih berkisar dari $(-34,5)-(-4,06)$ gram.

Tabel 1. Distribusi Frekuensi Sampel Berdasarkan Umur

\begin{tabular}{ccc}
\hline Umur (tahun) & Jumlah (n) & Persentase (\%) \\
\hline $36-45$ & 3 & 23 \\
$46-67$ & 10 & 77 \\
Total & 13 & 100 \\
\hline
\end{tabular}

Tabel 2. Distribusi Frekuensi Sampel Berdasarkan Berat Badan

\begin{tabular}{cccccc}
\hline Nama & \multicolumn{3}{c}{ Berat Badan $(\mathbf{k g})$} & & \\
\cline { 2 - 4 } Sampel & Pre HD & Post HD & Selisih & IDWG (\%) & Keterangan \\
\hline Ny. S & 57,3 & 56,7 & 0.6 & 1,04 & Ringan \\
Ny. Mi & 60 & 60 & 0 & 0 & - \\
Ny. Ma & 40 & 39 & 1 & 2,5 & Ringan \\
Ny. H & 58 & 57 & 1 & 1,72 & Ringan \\
Ny. I & 48 & 46 & 2 & 4,16 & Sedang \\
Ny. ST & 65,7 & 65 & 0.7 & 1,06 & Ringan \\
Ny. Y & 55 & 54 & 1 & 1,81 & Ringan \\
Ny. Si & 45 & 44 & 1 & 2,22 & Ringan \\
Tn. YM & 70 & 67 & 3 & 4,28 & Sedang \\
Ny. SR & 55 & 55 & 0 & 0 & - \\
Ny. N & 46 & 46 & 0 & 0 & - \\
Ny. Sa & 50 & 50 & 0 & 0 & - \\
Ny. Mh & 49 & 48 & 1 & 2,04 & Ringan \\
\hline
\end{tabular}


J.Gipas, November 2018, Volume 2 Nomor 2 ISSN 2599-0152 eISSN 2599-2465 http://jos.unsoed.ac.id/index.php/jgps

Tabel 3. Distribusi Frekuensi Sampel Berdasarkan Jenis Kelamin

\begin{tabular}{ccc}
\hline Jenis Kelamin & Jumlah (n) & Persentase (\%) \\
\hline Laki-laki & 1 & 8 \\
Perempuan & 12 & 92 \\
Total & 13 & 100 \\
\hline
\end{tabular}

Tabel 4. Distribusi Frekuensi Sampel Berdasarkan Pendidikan

\begin{tabular}{ccc}
\multicolumn{2}{c}{ Tabel 4. Distribusi Frekuensi Sampel Berdasarkan Pendidikan } \\
\hline Tingkat Pendidikan & Jumlah $(\mathbf{n})$ & Persentase (\%) \\
\hline Pendidikan Dasar & 6 & 46,1 \\
Pendidikan Menengah & 5 & 38,5 \\
Pendidikan Tinggi & 2 & 15,4 \\
Total & 13 & 100 \\
\hline
\end{tabular}

Tabel 5. Distribusi Frekuensi Sampel Berdasarkan Pekerjaan

\begin{tabular}{ccc} 
Tabel 5. Distribusi Frekuensi Sampel Berdasarkan Pekerjaan \\
\hline Pekerjaan & Jumlah (n) & Persentase (\%) \\
\hline Bekerja & 2 & 15 \\
Tidak Bekerja & 11 & 85 \\
Total & 13 & 100 \\
\hline
\end{tabular}

Tabel 6. Distribusi Frekuensi Sampel Berdasarkan Asupan Protein Pre Dan Post Hemodialisa

\begin{tabular}{ccccccc}
\multicolumn{7}{c}{ Pre Dan Post Hemodialisa } \\
\hline Nama & \multicolumn{7}{c}{ Pre } & Post \\
Sampel & $\begin{array}{c}\text { Asupan } \\
\text { (gram) }\end{array}$ & $\begin{array}{c}\text { Kebutuhan } \\
\text { (gram) }\end{array}$ & $\begin{array}{c}\text { Selisih } \\
\text { (gram) }\end{array}$ & $\begin{array}{c}\text { Asupan } \\
\text { (gram) }\end{array}$ & $\begin{array}{c}\text { Kebutuhan } \\
\text { (gram) }\end{array}$ & $\begin{array}{c}\text { Selisih } \\
\text { (gram) }\end{array}$ \\
\hline Ny. S & 61.55 & 45.36 & +16.19 & 41.3 & 45.36 & -4.06 \\
Ny. Mi & 18.9 & 48 & -29.1 & 25.7 & 48 & -22.3 \\
Ny. Ma & 37.4 & 31.2 & +6.2 & 13.9 & 31.2 & -17.3 \\
Ny. H & 12.95 & 45.6 & -32.65 & 20.2 & 45.6 & -25.4 \\
Ny. I & 19.3 & 36.8 & -17.5 & 15.1 & 36.8 & -21.7 \\
Ny. ST & 26.35 & 52 & -25.65 & 28.5 & 52 & -23.5 \\
Ny. Y & 46.45 & 43.2 & +3.25 & 14.25 & 43.2 & -28.95 \\
Ny. Si & 11.7 & 35.2 & -23.5 & 12.95 & 35.2 & -22.25 \\
Tn. YM & 41.5 & 53.6 & -12.1 & 26.75 & 53.6 & -26.85 \\
Ny. SR & 36.6 & 44 & -7.4 & 23.45 & 44 & -20.55 \\
Ny. N & 6.75 & 36.8 & -30.05 & 2.3 & 36.8 & -34.5 \\
Ny. Sa & 73.45 & 40 & +33.45 & 67.2 & 40 & +27.2 \\
Ny. Mh & 42.35 & 38.4 & +3.95 & 29.35 & 38.4 & -9.05 \\
\hline
\end{tabular}

Distribusi frekuensi berdasarkan asupan natrium pre dan post hemodialisa sampel dapat dilihat pada tabel 7 . Berdasarkan tabel 7, dapat diketahui bahwa untuk asupan natrium pre HD dari 13 sampel asupan berkisar dari 184,3-2357,35 mg dan asupan natrium post HD berkisar dari 9,7-2781,75 mg dengan hasil selisih berkisar dari (2321.85) - 1076.6 mg. Hasil selisih asupan pre dan post HD pada tabel dengan tanda (-) menunjukkan bahwa asupan natrium dari bahan makanan maupun minuman tidak melebihi kebutuhan natrium per hari dan begitu pun sebaliknya hasil selisih asupan pre 
J.Gipas, November 2018, Volume 2 Nomor 2 ISSN 2599-0152 eISSN 2599-2465 http://jos.unsoed.ac.id/index.php/jgps

dan post HD pada tabel dengan tanda (+) dari bahan makanan maupun minuman menunjukkan bahwa asupan natrium melebihi kebutuhan natrium per hari.

Tabel 7. Distribusi Frekuensi Sampel Berdasarkan Asupan Natrium

\begin{tabular}{cccc} 
& \multicolumn{3}{c}{ Pre Dan Post HD } \\
\hline \multirow{2}{*}{ Nama Sampel } & Pre $(\mathbf{m g})$ & Post $\mathbf{( m g})$ & Selisih $(\mathbf{m g})$ \\
\cline { 2 - 4 } Ny. S & 1705.15 & 2781.75 & +1076.6 \\
Ny. Mi & 804.45 & 714.8 & -89.65 \\
Ny. Ma & 2357.35 & 35.5 & -2321.85 \\
Ny. H & 607.4 & 196.5 & -410.9 \\
Ny. I & 346.3 & 706.2 & +359.9 \\
Ny. ST & 1385.05 & 87.85 & -1297.2 \\
Ny. Y & 1414.3 & 955.2 & -459.1 \\
Ny. Si & 184.3 & 129.5 & -54.8 \\
Tn. YM & 504.25 & 1076.2 & +571.95 \\
Ny. SR & 583.1 & 687.1 & +104 \\
Ny. N & 237.75 & 9.7 & -228.05 \\
Ny. Sa & 1507.4 & 756.6 & -750.8 \\
Ny. Mh & 662.5 & 858.2 & +195.7 \\
\hline
\end{tabular}

Distribusi frekuensi berdasarkan asupan kalium pre dan post hemodialisa sampel dapat dilihat pada tabel 8 .

Berdasarkan tabel 8. Dapat diketahui bahwa untuk asupan kalium pre hemodialisa dari 13 sampel asupan berkisar dari 142,85 mg - 1768,4 mg dan asupan kalium post HD berkisar dari 98,3 - 1419,15 mg. Adapun selisih asupan pre HD rata-rata dibawah kebutuhan berkisar antara (-2089.95) - (499.6) mg dan rata rata selisih asupan post HD berkisar antara (-1873.95) - (848.85) mg. Hasil selisih asupan pre dan post HD pada tabel dengan tanda (-) menunjukkan bahwa asupan kalium dari bahan makanan maupun minuman tidak melebihi kebutuhan kalium per hari.

Distribusi frekuensi berdasarkan asupan cairan pre dan post hemodialisa sampel dapat dilihat pada tabel 9.

Berdasarkan tabel 9. Diketahui bahwa untuk asupan cairan pre HD dari 13 sampel asupan berkisar dari 90,35 940,2 $\mathrm{ml}$ dan asupan cairan post HD berkisar dari 35,9 - 790,8 ml dengan selisih asupan pre dan post HD yaitu berkisar dari $(-272,75)-482.65 \mathrm{ml}$. 
J.Gipas, November 2018, Volume 2 Nomor 2 ISSN 2599-0152 eISSN 2599-2465 http://jos.unsoed.ac.id/index.php/igps

Tabel 8. Distribusi Frekuensi Sampel Berdasarkan Asupan Kalium

\begin{tabular}{|c|c|c|c|c|c|c|}
\hline \multirow[b]{3}{*}{$\begin{array}{c}\text { Nama } \\
\text { Sampel }\end{array}$} & \multicolumn{6}{|c|}{ Pre Dan Post HD } \\
\hline & \multicolumn{3}{|c|}{ Pre } & \multicolumn{3}{|c|}{ Post } \\
\hline & $\begin{array}{c}\text { Asupan } \\
\text { (mg) }\end{array}$ & $\begin{array}{c}\text { Kebutuhan } \\
\text { (mg) }\end{array}$ & $\begin{array}{c}\text { Selisih } \\
\text { (mg) }\end{array}$ & $\begin{array}{c}\text { Asupan } \\
\text { (mg) }\end{array}$ & $\begin{array}{c}\text { Kebutuhan } \\
\text { (mg) }\end{array}$ & $\begin{array}{c}\text { Selisih } \\
\text { (mg) }\end{array}$ \\
\hline Ny. S & 1768.4 & 2268 & -499.6 & 1419.15 & 2268 & -848.85 \\
\hline Ny. Mi & 310.05 & 2400 & -2089.95 & 598.7 & 2400 & -1801.3 \\
\hline Ny. Ma & 718.65 & 1560 & -778.14 & 175.9 & 1560 & -1384.1 \\
\hline Ny. H & 256.95 & 2280 & -2023.05 & 406.05 & 2280 & -1873.95 \\
\hline Ny. I & 326.1 & 1840 & -1513.9 & 310.7 & 1840 & -1529.3 \\
\hline Ny. ST & 658.6 & 2600 & -1941.4 & 739.3 & 2600 & -1860.7 \\
\hline Ny. Y & 797.95 & 2160 & -1362.05 & 343.55 & 2160 & -1816.45 \\
\hline Ny. Si & 142.85 & 1760 & -1617.15 & 238.45 & 1760 & -1521.55 \\
\hline Tn. YM & 617.25 & 2680 & -2062.75 & 757.5 & 2680 & -1922.5 \\
\hline Ny. SR & 504.4 & 2200 & -1695.6 & 381.45 & 2200 & -1818.55 \\
\hline Ny. N & 161.8 & 1840 & -1678.2 & 98.3 & 1840 & -1741.7 \\
\hline Ny. Sa & 1268.15 & 2000 & -731.85 & 811.55 & 2000 & -1188.45 \\
\hline Ny. Mh & 980.85 & 1920 & -939.15 & 552.85 & 1920 & -1367.15 \\
\hline
\end{tabular}

Tabel 9. Distribusi Frekuensi Sampel Berdasarkan Asupan Cairan Pre Dan Post HD

\begin{tabular}{cccc}
\hline \multicolumn{3}{c}{ Pre Dan Post HD } \\
\cline { 2 - 4 } Nama Sampel & Pre $(\mathbf{m l})$ & Post $(\mathbf{m l})$ & Selisih $(\mathbf{m l})$ \\
\cline { 2 - 4 } Ny. S & 545.15 & 420.05 & -125.1 \\
Ny. Mi & 340.55 & 575.4 & +234.85 \\
Ny. Ma & 90.35 & 35.9 & -54.45 \\
Ny. H & 429.55 & 350.2 & -79.35 \\
Ny. I & 246 & 294.05 & +48.05 \\
Ny. ST & 171.1 & 105.75 & -65.35 \\
Ny. Y & 940.2 & 667.45 & -272.75 \\
Ny. Si & 318.25 & 214.85 & -103.4 \\
Tn. YM & 445 & 498.15 & +53.15 \\
Ny. SR & 440.5 & 392.55 & -47.95 \\
Ny. N & 162.3 & 224.35 & +62.05 \\
Ny. Sa & 633.1 & 641.95 & +8.85 \\
Ny. Mh & 308.15 & 790.8 & +482.65 \\
\hline
\end{tabular}

Karakteristik sampel yang tersaji pada tabel 1. Menunjukan usia sampel berada pada kelompok lanjut usia. Peningkatan prevalensi penyakit gagal ginjal kronik diakibatkan oleh perubahan struktur fungsional ginjal, pada usia tua terjadi penurunan kecepatan aliran darah ke ginjal, selain itu juga dipengaruhi oleh perubahan massa otot. Hasil penelitian ini sejalan dengan penelitian yang dilakukan oleh Fauziah, E, A., Hidayat,
N., \& Suryani, I., 2017, pada 40 orang pasien gagal ginjal kronik di Unit Hemodialisa RS PKU Muhammadiyah Yogyakarta, terjadi peningkatan kejadian penyakit gagal ginjal kronik dari $17,5 \%$ pada usia 36-45 tahun menjadi $62,5 \%$ pada usia 46-65 tahun.

Penimbangan berat badan sampel yang tersaji pada tabel 2. Dilakukan baik sebelum dan sesudah hemodialisis untuk mengetahui kondisi cairan dalam tubuh, 
kemudian IDWG (Interdialytic Weight

Gain) dihitung berdasarkan berat badan kering setelah hemodialisis (Istanti, 2014). Hasil IDWG berkisar dari 0$4,28 \%$ dan ada 2 sampel dengan kategori sedang dengan nilai IDWG 4,16\% dan 4,28\% dimana menurut Neuman, 2013, IDWG yang dapat ditoleransi oleh tubuh adalah tidak lebih dari 3\% dari berat kering.

Berat kering adalah berat tubuh tanpa adanya kelebihan cairan yang menumpuk diantara dua terapi hemodialisa (Mitchel, 2002). Tindakan hemodialisis dilakukan untuk menarik cairan pasien sampai mencapai target berat badan kering pasien. Berat kering adalah berat terendah yang dapat ditoleransi oleh pasien sesaat setelah terapi dialisis tanpa menyebabkan timbulnya gejala turunnya tekanan darah, kram atau gejala lainnya yang merupakan indikasi terlalu banyak cairan dibuang (Reams \& Elder, 2003 dalam Suwitra, 2007).

Menurut penelitian Wahyudi \& Fitri, 2012, berat badan pre dialisis akan mempengaruhi program hemodialisis yang dilakukan. Hasil penelitian dari 25 orang sampel menunjukkan $72 \%$ tetap bahkan $8 \%$ turun yang memberikan gambaran bahwa status kesehatan yang
J.Gipas, November 2018 , Volume 2 Nomor 2 ISSN 2599-0152 eISSN 2599-2465 http://jos.unsoed.ac.id/index.php/jgps

dialami pasien telah menggambarkan keberhasilan terapi yang diberikan.

Karakteristik sampel yang tersaji pada tabel 3. Terbanyak berjenis kelamin perempuan karena secara konsisten memiliki kualitas hidup lebih buruk daripada laki-laki. Perempuan memiliki tugas domestik yang menjadi tanggung jawabnya (Mollaoglu, 2013). Hasil penelitian ini didukung oleh penelitian yang dilakukan oleh G, Yemima, V, W., Kanine, E., \& Wowiling, F., 2013, dimana responden yang terbanyak adalah perempuan yaitu 50,8\% dan lakilaki yaitu $49,2 \%$.

Tingkat pendidikan sampel yang tersaji pada tabel 4. Terbanyak dengan tingkat pendidikan dasar. Semakin tinggi pendidikan seseorang maka akan semakin cepat memahami tentang kondisi penyakit yang dialami Kurangnya pengetahuan dan kesadaran masyarakat untuk deteksi dini dalam memeriksakan dirinya ke pusat pelayanan kesehatan menjadi penyebab meningkatnya pasien gagal ginjal kronik dikarenakan pada stadium awal tidak merasakan keluhan spesifik. Kebanyakan pasien datang dengan keluhan yang sudah berat dan pada saat dilakukan pemeriksaan lanjutan sudah berada pada stadium terminal (stadium 
5) (Wibisono, 2014). Hasil penelitian yang sama mengemukakan bahwa frekuensi pendidikan pasien gagal ginjal kronis yang menjalani hemodialisa di RSU Dr. Zainoel Abidin Banda Aceh paling banyak pada kategori berpendidikan rendah/dasar yaitu 24 orang $(38,1 \%)$ (Rukmaliza, 2013).

Pekerjaan sampel yang tersaji pada tabel 5. Terbanyak dengan kategori tidak bekerja atau sebagai ibu rumah tangga. Hasil penelitian ini sejalan dengan penelitian yang dilakukan Rini, 2013, yang menyatakan pekerjaan responden pasien GGK mayoritas adalah tidak bekerja yaitu sebanyak 55 orang atau 75,3\%. Pasien dapat terus melakukan pekerjaan dan aktivitasnya apabila pasien rutin dalam mematuhi jadwal terapi hemodialisis yang telah terjadwal, walaupun yang dilakukan tidak semaksimal sebelum pasien divonis harus menjalani terapi hemodialisis.

Perhitungan kebutuhan protein yang tersaji pada tabel 6. Berdasarkan standar diet RSUD dr. Doris Sylvanus Palangka Raya yang ada pada leaflet. Hasil selisih asupan pre dan post HD pada tabel dengan tanda (-) menunjukkan bahwa asupan protein dari bahan makanan maupun minuman tidak
J.Gipas, November 2018 , Volume 2 Nomor 2 ISSN 2599-0152 eISSN 2599-2465 http://jos.unsoed.ac.id/index.php/jgps

melebihi kebutuhan protein per hari dan begitu pun sebaliknya hasil selisih asupan pre dan post HD pada tabel dengan tanda (+) menunjukkan bahwa asupan protein dari bahan makanan maupun minuman melebihi kebutuhan protein per hari.

Berdasarkan pengakuan sampel, asupan protein pada post HD dengan tanda (-) atau negatif diakibatkan adanya gejala gangguan gastrointestinal dengan keluhan mual dan muntah. Muntah dapat disebabkan dampak hipotensi pasca hemodialisis dan muntah biasanya diiringi mual karena muntah merupakan manifestasi dari adanya mual yang berlebihan. Mual menimbulkan perasaan tidak nyaman pada perut sehingga membuat seseorang menolak makanan atau tidak mampu menghabiskan makanan yang disajikan (Khairunnisa 2012). Hal ini sejalan dengan penelitian yang dilakukan Lopes, 2007, proporsi sampel hemodialisa yang mengalami mual jumlahnya meningkat secara signifikan seiring semakin buruknya kondisi nafsu makan.

Hasil recall 24 jam, rata-rata presentase asupan protein nabati pada saat pre hemodialisa yaitu $37,1 \%$ dan sumber protein hewani sebesar $62,9 \%$. Rata-rata asupan protein nabati post 
hemodialisa, yaitu $32,5 \%$ dan protein hewani sebesar $67,5 \%$.

Berdasarkan hasil uji normalitas didapatkan hasil asupan protein pre dan post hemodialisa adalah berdistribusi normal ( $>0.05)$ yaitu asupan pre $(\mathrm{p}=0,570)$ dan asupan post $(\mathrm{p}=0,052)$. Hasil uji t-berpasangan dengan $\mathrm{p}<0,05$ menunjukkan bahwa ada perbedaan secara bermakna antara asupan protein pre dan post hemodialisa di RSUD dr. Doris Sylvanus Palangka Raya dengan nilai $\mathrm{p}$ value $=0,022$.

Protein berguna untuk pemeliharaan jaringan tubuh dan mengganti sel-sel yang rusak sebesar 0,8 $\mathrm{g} / \mathrm{kg}$ BB. Jumlah dan jenis protein yang diberikan pada pasien penyakit ginjal kronik pre dialisis dalam bentuk diet rendah protein sangat penting diperhatikan karena protein berguna untuk mengganti jaringan yang rusak, membuat zat antibodi, enzim dan hormon, menjaga keseimbangan asam basa, air, elektrolit, serta menyumbang sejumlah energi tubuh (Kresnawan, 2012)

Menurut Bastiansyah, 2008, dalam Dewi, 2015, pembatasan protein dilakukan karena terjadinya disfungsi ginjal dengan salah satu cirinya adalah terjadinya uremia. Pada keadaan normal
J.Gipas, November 2018 , Volume 2 Nomor 2 ISSN 2599-0152 eISSN 2599-2465 http://jos.unsoed.ac.id/index.php/jgps

ginjal akan mengeluarkan produk sisa metabolisme protein (ureum) yang berlebihan di dalam tubuh dalam bentuk urin namun sebaliknya apabila terjadi kerusakan pada ginjal maka akan terjadi penumpukan ureum di dalam darah sehingga ginjal tidak mampu mengeluarkannya dan menjadikannya semakin tinggi. Tingginya ureum dalam darah dapat menimbulkan bekuan ureum dan menimbulkan bau napas yang mengandung amonia. Kadar ureum yang berlebihan akan diubah oleh bakteri menjadi amonia, sehingga senyawa ini menjadi senyawa toksik/racun bagi tubuh. Efek yang ditimbulkan jika uremia terlalu tinggi adalah terjadinya perdarahan baik dihidung, bawah kulit maupun saat buang air besar.

Penderita gagal ginjal dengan dialisis dianjurkan asupan protein tinggi untuk mempertahankan keseimbangan nitrogen dan mengganti asam amino yang hilang selama dialisis dengan 50\% protein hendaknya bernilai biologis tinggi karena asupan protein sangat diperlukan mengingat fungsinya dalam tubuh. Asupan protein dapat dipengaruhi oleh konsumsi protein yang rendah dalam diit, asupan makanan yang kurang pengaruh dari melemahnya kekebalan tubuh. Pengaruh asupan 
J.Gipas, November 2018, Volume 2 Nomor ISSN 2599-0152 eISSN 2599-2465 http://jos.unsoed.ac.id/index.php/jgps

protein memegang peranan yang penting dalam penanggulangan gizi penderita gagal ginjal kronik, karena gejala sindrom uremik disebabkan menumpuknya katabolisme protein tubuh oleh karena itu semakin baik asupan protein semakin baik pula dalam mempertahankan status gizinya (Almatsier, 2004).

Perbedaan asupan natrium sampel tersaji pada tabel 7. Hasil asupan pre dan post HD sampel telah sesuai dengan rekomendasi dari CARI, 2013, yaitu asupan natrium pada pasien hemodialisis yaitu kurang dari 2,4 gram/hari atau berkisar 1000-2300 mg/hari (Susetyowati., Faza, F., \& Hayu, I, A., 2017)

Hasil recall 24 jam untuk bahan makanan sumber natrium yang paling banyak dikonsumsi pada pre HD yaitu roti putih, biskuit, ikan asin, putih telur ayam dan garam. Pada post HD bahan makanan sumber natrium yang paling banyak dikonsumsi yaitu biskuit, udang, putih telur ayam, garam dan kecap asin. Asupan natrium harus dibatasi hingga tanpa tambahan garam dalam diet. Pasien harus diedukasi mengenai garam yang menjadi pemicu utama terhadap rasa haus, karena pembatasan asupan natrium mungkin menyebabkan pengendalian cairan (dan tekanan darah) yang lebih baik daripada upaya membatasi asupan cairan saja (Joan, 2014). Rata-rata pasien merasa makanannya terasa hambar apabila tidak diberi garam atau penyedap rasa. Hal tersebut merupakan pemicu rasa haus pada pasien. Dan apabila dibiarkan maka akan memperparah kerja ginjal untuk mensekresi zat sampah yang ada dalam tubuh (Joan, 2014).

Berdasarkan hasil uji normalitas didapatkan hasil asupan natrium pre dan post HD adalah berdistribusi tidak normal $(\mathrm{p}=<0.05)$ yaitu asupan pre $(\mathrm{p}=0,160)$ dan asupan post $(\mathrm{p}=0,003)$. Hasil uji Wilcocxon dengan $\mathrm{p}>0,05$ menunjukkan bahwa tidak ada perbedaan secara bermakna antara asupan natrium pre dan post hemodialisa di RSUD dr. Doris Sylvanus Palangka Raya dengan nilai p value $=0,382$.

Secara fisiologis, keseimbangan natrium dan volume plasma ekstraseluler diatur oleh ekskresi natrium renal. Saat terjadi penurunan laju filtrasi glomerulus (GFR), kompensasi ginjal ialah dengan menaikkan fraksi ekskresi natrium (FNA). Namun pada GGK, mekanisme kompensasi ini menurun, sehingga diet rendah garam sekalipun terkadang masih 
J.Gipas, November 2018, Volume 2 Nomor 2 ISSN 2599-0152 eISSN 2599-2465 http://jos.unsoed.ac.id/index.php/jgps

menimbulkan retensi natrium

(Ramadani, 2013)

Hasil nilai IDWG 4,16\% dan $4,28 \%$ pada dua sampel dengan kategori sedang menunjukkan bahwa selisih asupan natrium yaitu $+359,9 \mathrm{mg}$ dan $+571,95 \mathrm{mg}$. Hal ini telah sesuai dengan teori Ramadani, 2013, pada pasien GGK dengan dialisis, asupan natrium berlebih terbukti menaikkan IDWG, resiko hipertensi, edema dan gagal jantung. Seiring dengan retensi natrium, GGK juga menimbulkan retensi cairan. Kelebihan asupan air akan memperberat overload volume dan menaikkan IDWG, dimana air mempengaruhi tonus plasma dan volume sel-sel tubuh. Stimulasi rasa haus dan FNA renal merupakan dua komponen utama dalam menjaga keseimbangan cairan tubuh.

Menurut Krummel, 2004, bahwa responden yang mengkonsumsi natrium dalam jumlah yang kecil (2737 mg/hari) terbukti memiliki risiko hipertensi yang rendah pula. Teori lain juga menyatakan bahwa pembatasan asupan natrium pada pasien GGK bertujuan untuk mengendalikan tekanan darah dan edema (Suwitra, 2006).

Perbedaan asupan kalium sampel tersaji pada tabel 8. Menunjukan bahwa tidak terdapat perbedaan baik sebelum dan sesudah HD karena asupannya kurang dari kebutuhan. Asupan kalium pada pasien hemodialisis yang direkomendasikan oleh ADA, 2002, yaitu sebesar $40 \mathrm{mg} / \mathrm{kg}$ berat badan tanpa edema. Pembatasan kalium sangat diperlukan karena itu makanan tinggi kalium seperti buah-buahan dan umbiumbian tidak dianjurkan dikonsumsi (Sudoyo, A. W., Setiyohadi, B., Alwi, I., K, M. S., \& Setiati, S, 2009).

Hasil recall 24 jam untuk bahan makanan sumber kalium yang paling banyak dikonsumsi pada pre HD yaitu kentang, singkong, jagung kuning, biskuit, ayam, daging sapi, daun pepaya muda, kol, bayam, pisang, apel hijau, pepaya, anggur, dan teh. Pada post HD bahan makanan sumber kalium yang paling banyak dikonsumsi yaitu singkong, biskuit, roti coklat, ayam, udang, kol, bayam, daun pepaya muda, buncis, anggur, teh dan kecap asin. Pasien gagal ginjal kronik diberikan diet rendah kalium, karena pada pasien gagal ginjal kronik biasanya hiperkalemia sehingga mengakibatkan disritmia atau henti jantung, amonia ginjal menurun, ekskresi hidrogen menurun dan asidosis. Pasien hemodialisa dianjurkan untuk membatasi makanan yang mengandung 
kalium, air dan garam (Marantika \& Devi, 2014).

Berdasarkan hasil uji normalitas didapatkan hasil asupan kalium pre dan post HD adalah berdistribusi tidak normal $(\mathrm{p}=<0.05)$ yaitu asupan pre $(\mathrm{p}=0,000)$ dan asupan post $(\mathrm{p}=0,120)$. Hasil uji Wilcocxon dengan $\mathrm{p}>0,05$ menunjukkan bahwa tidak ada perbedaan secara bermakna antara asupan kalium pre dan post HD di RSUD dr. Doris Sylvanus Palangka Raya dengan nilai $\mathrm{p}$ value yang didapat yaitu $=0,075$.

Asupan kalium yang berlebihan dalam waktu yang lama dapat menyebabkan tingginya kadar kalium dalam darah. Apabila kadar kalium dalam darah tinggi atau hiperkalemia, dapat menyebabkan irama jantung menjadi tidak teratur, terutama pada penderita jantung. Selain itu, untuk mengetahui kelebihan kalium dalam tubuh lebih akurat dengan pengecekan laboratorium dari kalium darah. Teori ini diperkuat oleh hasil penelitian Korgaonkar S, Anca Tilea, Fredric Finkelstein, Peter Kotanko, Brenda W. G,Margaret Kiser, Bertram Pitt, dan Rajiv Saran, 2010, didapatkan hasil bahwa serum kalium di dalam tubuh, dapat di kontrol dengan modifikasi diet
J.Gipas, November 2018 , Volume 2 Nomor 2 ISSN 2599-0152 eISSN 2599-2465 http://jos.unsoed.ac.id/index.php/jgps

dari asupan kalium. Penelitian ini dilakukan selama 2 tahun 6 bulan pada pasien gagal ginjal kronik yang menjalani hemodialisa sebanyak 820 pasien. Selain itu, sejalan dengan penelitian Annisa, 2016, didapatkan hasil ada hubungan antara asupan kalium dengan kadar kalium pada pasien gagal ginjal kronik yang menjalani hemodialisa rawat jalan di RSUD Kabupaten Sukoharjo dengan $\mathrm{p}=0,000$ (p $>0,05)$.

Perbedaan asupan cairan sampel tersaji pada tabel 9. Menunjukan bahwa terdapat perbedaan antara sebelum dan sesudah HD. Bila asupan cairan berlebihan maka periode di antara dialisis akan terjadi kenaikan berat badan yang besar (Sudoyo, A. W., Setiyohadi, B., Alwi, I., K, M. S., \& Setiati, S, 2009). Hasil nilai IDWG 4,16\% dan 4,28\% pada dua sampel dengan kategori sedang menunjukkan bahwa selisih asupan cairan yaitu $+48,05 \mathrm{ml}$ dan $+53,15$ ml. Cairan yang diminum penderita gagal ginjal harus diawasi dengan seksama karena rasa haus bukan lagi petunjuk yang dapat digunakan untuk mengetahui hidrasi tubuh. Asupan yang terlalu bebas dapat mengakibatkan beban sirkulasi menjadi berlebihan, edema dan intoksikasi air. Sedangkan 
J.Gipas, November 2018, Volume 2 Nomor 2 ISSN 2599-0152 eISSN 2599-2465 http://jos.unsoed.ac.id/index.php/jgps

asupan yang terlalu sedikit akan mengakibatkan dehidrasi, hipotensi dan memperberat gangguan fungsi ginjal. Parameter yang tepat untuk diamati selain data asupan dan pengeluaran cairan yang dicatat dengan tepat adalah pengukuran berat badan harian. Pasien harus mematuhi pembatasan cairan agar mendapatkan berat badan kering. Interdyalitic weight gain (IDWG) merupakan indikator untuk mengetahui jumlah cairan yang masuk selama periode interdialitik dan kepatuhan pasien terhadap pengaturan cairan pada pasien yang mendapat terapi HD (Thomas, 2003).

Hasil penelitian yang dilakukan oleh Istanti, 2014, menunjukkan bahwa ada hubungan yang signifikan antara masukan cairan dengan IDWG ( $\mathrm{r}=0.541$, $\mathrm{p}$-value $=0.000)$. Arah hubungan adalah positif yang berarti semakin banyak masukan cairan responden maka IDWG juga akan meningkat. Besaran koefisien determinan masukan cairan adalah $29.30 \%$, berarti masukan cairan menentukan 29.30\% IDWG, sisanya $70,70 \%$ ditentukan oleh faktor lain.

Berdasarkan hasil uji normalitas didapatkan hasil asupan cairan pre dan post HD adalah berdistribusi normal $(\mathrm{p}=>0.05)$ yaitu asupan pre $(\mathrm{p}=0,311)$ dan asupan post $(\mathrm{p}=0,979)$. Hasil uji statistik $t$-berpasangan dengan $\mathrm{p}>0,05$ menunjukkan bahwa tidak ada perbedaan secara bermakna antara asupan cairan pre dan post HD di RSUD dr. Doris Sylvanus Palangka Raya dengan nilai $\mathrm{p}$ value yang didapat yaitu $=0,836$.

Pembatasan asupan cairan pada pasien gagal ginjal kronik yang menjalani hemodialisa merupakan hal yang sangat penting untuk diperhatikan, karena asupan cairan yang berlebihan dapat mengakibatkan kenaikan berat badan, edema, bronkhi basah dalam paru-paru, kelopak mata yang bengkak dan sesak nafas yang diakibatkan oleh volume cairan yang berlebihan. Cairan yang diminum pasien yang menjalani hemodialisa harus diawasi dengan seksama. Beberapa pasien mengalami kesulitan dalam membatasi asupan cairan yang masuk, namun mereka tidak mendapatkan pemahaman tentang bagaimana strategi yang dapat membantu mereka dalam pembatasan cairan (Tovazzi \& Mazzoni, 2012). Meskipun pasien sudah mengerti bahwa kegagalan dalam pembatasan cairan dapat berakibat fatal, namun sekitar $50 \%$ pasien yang menjalani terapi hemodialisis tidak mematuhi 
pembatasan

cairan

yang

direkomendasikan (Barnett T, Li-Yoong

T, Pinikahana J, Si-Yen,T., 2007)

Hasil penelitian yang dilakukan oleh Novitasari, D., Candra, D, A, K., \& Sudyasih, T., 2015, dari 60 sampel menunjukkan $71,7 \%$ responden pada kategori patuh. Pasien GGK yang tidak mematuhi pembatasan asupan cairan akan mengalami penumpukan cairan sehingga menyebabkan edema paru dan hipertropi pada ventrikel kiri. Penumpukan cairan dalam tubuh menyebabkan fungsi kerja jantung dan paru-paru berat, sehingga mengakibatkan pasien cepat lelah dan sesak. Aktivitas fisik juga akan mengalami gangguan, baik pada saat beraktivitas ringan maupun sedang.

\section{KESIMPULAN}

Ada perbedaan asupan protein pre dan post hemodialisa di RSUD dr. Doris Sylvanus Palangka Raya serta tidak ada perbedaan asupan natrium, kalium, cairan pre dan post hemodialisa di RSUD dr. Doris Sylvanus Palangka Raya. Diharapkan penderita PGK agar tetap menjaga jumlah asupan protein pre dan post hemodialisa serta jumlah asupan natrium, kalium dan cairan agar
J.Gipas, November 2018, Volume 2 Nomor 2 ISSN 2599-0152 eISSN 2599-2465 http://jos.unsoed.ac.id/index.php/jgps

tidak terjadi kelebihan dan kekurangan asupan zat gizi.

\section{DAFTAR PUSTAKA}

American Dietetic Association. 2010. Nutrition Diagnosis: A Critical Step In The Nutrition Care Process

Annisa H. 2016. Hubungan Kepatuhan Diet dan Asupan Kalium dengan Kadar Kalium Pada Pasien Gagal Ginjal Kronik Yang Menjalani Hemodialisa Rawat Jalan Di RSUD Kabupaten Sukoharjo. Skripsi, Universitas Muhammadiyah Surakarta.

Asmadi. 2008. Konsep Dasar Keperawatan. EGC. Jakarta

Barnett T, Li-Yoong T, Pinikahana J, Si-Yen T. 2007. Fluid Compliance among Patients Having Haemodialysis: Canan Educational Programme Make A Difference. Journal of Advanced Nursing.

Budiarto dan Anggraeni. 2002. Pengantar Epidemiologi, Edisi 2. EGC. Jakarta

Dewi S P. 2010. Hubungan Lama Periode Hemodialisis dengan Status Albumin Penderita Gagal Ginjal Kronik Di Unit Hemodialisis RSUD. Prof. Dr. Margono Soekarjo Purwokerto

Dewi S P. 2015. Hubungan Lamanya Hemodialisa Dengan Kualitas Hidup Pasien Gagal Ginjal di RS PKU Muhammadiyah Yogyakarta.

El M, Suryani I \& S N.H. 2015. Hubungan Asupan Energi, Protein, Lemak, Karbohidrat dan Lemak Hemodialis Terhadap Status Gizi pada Pasien Gaga Ginjal yang Menjalani Hemodialisa di RSUD Panembahan Senopati Bantul. Jurnal Nutrisia, Vol. 17.

Fatmawati I \& Rahmawati T. 2016. Hubungan Asupan Natrium dengan Tekanan Darah Pada Pasien Gagal Ginjal Kronik yang Menjalani Hemodialisis. Profesi, 13 Nomor 2.

Fauziah E A., Hidayat N., \& Suryani I., 2017. Hubungan Antara Asupan Protein dan Asupan Kalium Dengan Kadar Ureum Dan Kreatinin Pada Pasien Gagal Ginjal Kronik Dengan Hemodialisa Di RS PKU Muhammadiyah Yogyakarta. Skripsi. Poltekkes Kemenkes Yogyakarta

G Yemima V W., Kanine E., \& Wowiling F. 2013. Mekanisme Koping Pada Pasien
Commented [Y2]: Nama author?

Commented [Y3]: Cetak miring pada nama jurnal, mohon sekal lagi melihat panduan 
Penyakit Ginjal Kronik Yang Menjalani Terapi Hemodialisis Di Rumah Sakit Prof. Dr.R.D Kandou Manado. Jurnal Keperawatan, Volume 1 Nomor 1

Hasanah I P F., 2016. Hubungan Asupan Protein dan Zat Besi dengan Kadar Hemoglobin Pada Pasien Gagal Ginjal Kronik Post Hemodialisis Di Unit Hemodialisis RSUD Kabupaten Sukoharjo. Skripsi. Universitas Muhammadiyah Surakarta.

Indonesian Renal Registry (IRR). 2013. Report of Indonesian Renal Registry

Istanti. 2014. Hubungan Antara Masukan Cairan Dengan Interdyalitic Weight Gain (IDWG) Pada Pasien Chronic Kidney Disease Di Unit Hemodialisis RS PKU Muhammadiyah Yogyakarta

Istanti. 2009. Faktor-Faktor yang Berkontribusi Terhadap Interdialytic Weight Gains (IDWG) Pada Pasien Chronic Kidney Disease (CKD) Di Unit Hemodialisis RS PKU Muhammadiyah Yogyakarta.

Joan. 2014. Gizi \& Dietika. EGC. Jakarta

Khairunnisa A. 2012. Faktor-Faktor Yang Berhubungan Dengan Nafsu Makan Kurang pada Pasien Hemodialisis Di RSPAD Gatot Soebroto. Skripsi. Universitas Indonesia

Korgaonkar S, Anca Tilea, Fredric Finkelstein, Peter Kotanko, Brenda W G, Margaret Kiser, Bertram Pitt, dan Rajiv Saran. 2010. Serum Potassium and Outcomes in $C K D$ : Insights from the RRI-CKD Cohort Study. Journal Soc Nephron.

Kresnawan T. 2012. Diet Rendah Protein dan Penggunaan Protein Nabati pada Penyakit Ginjal Kronik. RSCM. Jakarta.

Marantika Devi P N. 2014. Gambaran Kepatuhan Terhadap Anjuran Medis pada Pasien Gagal Ginjal Terminal yang Menjalani Terapi Hemodialisa di Kota Medan. Skripsi. Universitas Sumatera Utara.

Mitchell S. 2002. Estimated dry weight (EDW): aiming for accuracy. Journal Nephrology Nursing.

Mollaoglu. 2013. Quality of Life in Patient Undergoing Hemodialysis. Turkey: Cumhuriyet University.

Neumann C. 2013. Body Weight Telemetry is Useful to Reduce Interdialytic Weight Gain in Patients with End-Stange Renal Failure on Hemodialysis. Journal of the American Telemedicine. Vol.1

Novitasari D., Candra D A K. \& Sudyasih T. 2015. Hubungan Lama Hemodialisa dengan Kepatuhan Pembatasan Asupan
J Gipas, November 2018, Volume 2 Nomor 2 ISSN 2599-0152 eISSN 2599-2465 http://jos.unsoed.ac.id/index.php/igps

Cairan Pada Klien Hemodialisa Di RS PKU Muhammadiyah Unit 1 Yogyakarta. Profesi. STIKES Aisyisyah Yogyakarta.

Ramadani S. 2013. Korelasi Interdialytic Weight Gain dan Phase Angle pada Penderita Penyakit Ginjal Kronik dengan Hemodialisis Reguler. Tesis. Universitas Sumatera Utara

Rini S. 2013. Hubungan Antara Dukungan Keluarga Terhadap Kepatuhan dalam Pembatasan Asupan Nutrisi dan Cairan pada Pasien Gagal Ginjal Kronis dengan Hemodialisis. Jurnal Keperawatan Universitas Riau.

Rukmaliza. 2013. Hubungan Karakteristik Individu Dengan Kualitas Hidup Pasien Gagal Ginjal Kronik Yang Menjalani Hemodialisa di Instalasi Dialisis BLUD RSU DR. Zainoel Abidin Banda Aceh Tahun 2013

Sharif S S., Taslim N A. \& Bukhari A. 2012 Asupan Protein, Status Gizi pada Pasien Gagal Ginjal Tahap Akhir Yang Menjalani Hemodialisa Reguler. Jurnal Universitas Hasanuddin Makasar.

Sudoyo A W., Setiyohadi B., Alwi I K M S., \& Setiati S. 2009. Ilmu Penyakit Dalam Jilid II Edisi V. Internal Publishing. Jakarta.

Suhardjono. 2009. Penyakit Ginjal Kronik Adalah Suatu Wabah Baru (Global Epidemic) Di Seluruh Dunia. Annual Meeting Perhimpunan Nefrologi Indonesia.

Susetyowati, Faza F., \& Hayu I A. 2017. Gizi Pada Penyakit Ginjal Kronis. Gadjah Mada University Press. Yogyakarta.

Suwitra K. 2006. Gagal Ginjal Kronik. Buku Ajar Ilmu Penyakit Dalam. Jilid I, Edisi IV. Pusat Penerbitan Departemen Ilmu Penyakit Dalam FKUI. Jakarta

Suwitra K. 2007. Penyakit ginjal kronik. Dalam: Buku Ajar Ilmu Penyakit Dalam. Edito - Sudoyo, Aru W, dkk. Jakarta: Pusat Penerbitan IPD FKUI.

Tovazzi M E \& Mazzoni V. 2012. Personal Paths Of Fluid Setriction In Patient On Hemodialysis. Journal Nephrologi Nursing.

Wahyudi dan Fitri. 2012. Kepatuhan Diet dan Berat Badan Pre Hemodialisis pada Pasien Regular di Ruangan Hemodialisa RSUD Nganjuk. Jurnal Keperawatan

Wibisono D. 2014. Deteksi Dini Menjaga Kualitas dan Fungsi Ginjal. Edisi 11. Majalah Rumah Sakit Mitra Keluarga. 